\title{
Contact Analysis of Silicone Rubber Rectangular Ring in the Automatic Tighten Assembly
}

YOU JiaChuan, LIN JingDong, XU DaFa, HAO WenYuan.

The Rockwell Laboratory, College of Automation, Chongqing University, Chongqing 400044, China. E-mail: yjc_cqu@163.com,twtddv@163.com

According to the uniaxial tension model and coulomb friction theory, by considering the nonlinear mechanical properties of rubber, the effect of deformation quantities of silicone rubber rectangular sealing ring on the assembly torque in tightening assembly process is researched in this paper. A stress-strain numerical model of silicone rubber rectangular sealing ring in small deformation range is established when tightening, on this basis, the numerical model is derived in deformation quantities of rectangular ring and assembly torque. Then having the torque-angle experiments by automatic tightening machine. The results show that, compared with the practical engineering experiment, the numerical model that reveals the relationship between the deformation quantities of the rectangular sealing ring and Assembly torque can reflect the effect of deformation on the assembly torque during the actual assembly process with great accuracy, which has a great reference value for the automatic assembly.

Keywords: Torque-angle; Coulomb friction; Stress-strain; Finite element method; Silicone rubber rectangular sealing ring

\section{Acknowledgement}

The authors acknowledge the support from Chinese Equipment Manufacturing Unit and the Rockwell Laboratory of Chongqing University during the course of this study.

\section{References}

[1] NASSAR, S.A., YANG, X.J. (2007).Novel Formulation for the Tightening and Break-Away Torque Components in Threaded Fasteners. In: ASME J. Pressure Vessel Technol., Vol. 129. pp. 653 - 663.TTP. UNITED STATES.

[2] NASSAR, S.A., YANG, X.J. (2008).Torque-Angle Formulation of Threaded Fastener Tightening. In: ASME. J. Mech. Des, Vol. 130, No. 2, pp. 24501 - 24504.TTP. U.S.A.

[3] MAVREVSKI, R. (2014). SELECTION AND COMPARISON OF REGRESSION MODELS: ESTIMATION OF TORQUE-ANGLE RELATIONSHIPS.In: COMPTES RENDUS DE L ACADEMIE BULGARE DES SCIENCES, Vol. 67, No. 10, pp. 1345-1354.TTP. Sofia.

[4] XU, Y., PANG, Y., TAN, Y., LIU, H., LIANG, L., ZHU, Z., YUN, Z. (2014). Calculation Model of Torque-Angle Characteristic of Large Gap Magnetic Drives System. In: Journal of Basic Science and Engineering, Vol. 22, No. 2, pp. 391-399.TTP.China.

[5] NASSAR, S.A., YANG, X.J. (2007). Storage Life of Silicone Rubber Sealing Ring Used in Solid Rocket Motor. In: Chinese Journal of Aeronautics, Vol. 27, No. 6, pp. 1469 - 1476.TTP. China.

[6] NIKAS, G. K., SAYLES R.S. (2006).Modeling and Optimization of Composite Rectangular Reciprocating Seals [J]. In: Engineering Tribology Proc, Vol. 220, No. 4, pp. 395 - 412.

[7] SHEN, Y., ZHANG, W., NIU, D. (2013). Axial Compression of a Transversely Isotropic Incompressible Rectangular Rubber Ring. In: Advances in Theoretical and Applied Mechanics, Vol. 6, No. 1, pp. 27-32. TTP. Bulgaria.

[8] WENZHENG ZHANG, XUEGANG YUAN, HONGWU ZHANG, JIUSHENG REN. (2012). FINITE DEFORMATION OF A CLASS OF RECTANGULAR RUBBER RINGS SUBJECTED TO END AXIAL LOADS. In: Chinese Journal of solid mechanics: English version, Vol. 25, No. 2, pp. 144-151. TTP. China.

[9] Q, REN, T, CAI, C, AN, J, SONG, Z, LIU. (2007). Determination on Mooney-Rivlin Model Constants of Silicon Rubber “O”-ring. In: JOURNAL OF SOLID ROCKET TECHNOLOGY, Vol. 145, No. 2, pp. 130 - 134.TTP. China.

[10] NASSAR, S. A., SUN, T., ZOU, Q. (2006). The Effect of Coating and Tightening Speed on the Torque-Tension Relationship in Threaded Fasteners. In: Proceedings of the 2006 SAE World Congress: Experiments in Automotive Engineering-Experimental Test, pp. 205-220.TTP. Detroit.

[11] XIE, B. H., FU, M. F., \& LI, A. M. (2013). Theoretical Calculation and Experimental Study on Sung Torque and Angle for the Injector Clamp Tightening Bolt of Engine. In: Applied Mechanics and Materials, Vol.351-352, pp. $1284-1288$. TTP. U.S.A. 
[12] Y.JIANG. (2008). Nonlinear Finite Element Method, PP.64-70. Beijing Industrial University Press, Bei Jing.

[13] GREEN, I., ENGLISH, C. (1992). Analysis of Elastomeric O-ring Seals in Compression Using The FiniteElement Method[J]. In: Tribology Transaction, Vol. 35, No. 1, pp. 83-88.TTP. U.S.A.

[14] X.YANG, X.YAN, S.JIA. (2006). FRICTIONAL CONTACT ANALYSIS OF PACKER RUBBER WITH LARGE DEFORMATION BASED ON ADHESIVE-SLIP FRICTIONAL CONTACT METHOD. In: Journal of Mechanical Strength, Vol.170, No. 2, pp. 229 - 234.TTP. China.

[15] M.A. Cruz Gómez, E.A. Gallardo-Hernández. (2013). Rubber Steel Friction in Contaminated Contacts. In: Wear, Vol. 302, No. 1-2, pp. 1421 - 1425.TTP. Mexico.

[16] Y, WANG. (2008)The Friction and Test of Rubber [J]. In: Special rubber products, Vol. 2, No. 3 , pp. 55 - 62. TTP. China.

[17] NOVAK, M., DOLEZAL, R. (2012). G-Ratio in hardened steel grinding with different coolant. In Manufacturing Technology, vo. 12, No. 13, pp. 192-197. 